Biol Neonate 1990;58:I-VI

\title{
Contents, Vol. 58, 1990
}

\section{No. 1 Original Paper}

Development of Cholesterol Metabolism: The Effect of Diet Composition at Weaning

Hahn, P.; Srubiski, L 1

Age-Related Variations in Jejunum and Distal Colon Contractile Response to Thyrotropin-

Releasing Hormone in vitro

Heitkemper, M.M.; Bond, E.F 8

Steroid Hormone May Modulate Hepatic Somatomedin C Production in Newborn

Calves

Coxam, V.; Davicco, M.-J.; Durand, D.; Bauchard, D.; Opmeer, F.; Barlet, J.-P. ... 16 Attempts

for Identification of a Chorionic Gonadotrophin-Like Bioactivity in the Rat Placenta Which

Stimulates the Testosterone Secretion of the Fetal Testis in vitro

Habert, R.; Picon, R 24

Auditory Brainstem Response in Hyperbilirubinemic Rat: Part I

Kuriyama, M.; Konishi, Y.; Sudo, M 32

Transplacental Effect of Lead Compounds on Tissue Plasminogen Activator Activity, Plasminogen Activator Inhibition and Plasmin Inhibition

Smokovitis, A.; Kokolis, N.; Alexaki, E.; Tsafaris, F

Airway Anomalies in Newborn Infants: Detection by Tracheoscopy via Endotracheal

Tube

Deres, M.; Kosack, K.; Waldschmidt, J.; Obladen, M

50

Separation of the Umbilical Cord - Histological Findings

Oudesluys-Murphy, A.M.; den Hollander, J.C 54

Brief Communication

Effect of Neuromuscular Blockade on Fetal Oxidative Metabolism

Wilkening, R.B.: Boyle, D.W 57

No. 2 Original Paper

Lactate Movements in the Term Human Placenta in situ

Piquard, F.; Schaefer, A.; Dellenbach, P.; Haberey, P

Hyperthyrotropinemia in a Neonate with Normal Thyroid Hormone Levels: The Earliest

Diagnostic Clue for Pseudohypoparathyroidism

Yokoro, S.; Matsuo, M.; Ohtsuka, T.; Ohzeki, T

Implantation and in vivo Antagonistic Effects of Antibiotic-Susceptible Escherichia coli

Strains Administered to Premature Newborns

Rastegar Lari, A.; Gold, F.; Borderon, J.C; Laugier, J.; Lafont, J.-P 73

Contents

Dependency of Doppler Parameters in the Anterior Cerebral Artery on Behavioural States

in Preterm and Term Neonates

Jorch, G.; Huster, T.; Rabe, H 79 
Human Cord Blood Lymphocytes Do Not Simultaneously Express CD4 and CD8 Cell Surface Markers ·

Reason D.C.; Ebisawa, M.; Saito, H.; Nagakura, T.; Iikura, Y

Effects of Adenosine and Its Analogues on Isolated Internal Carotid Arteries from Newborn and Adult Pigs

Laudignon, N.; Aranda, J.V.; Varma, D.R 91

Effect of a Popular Chinese Herb on Neonatal Bilirubin Protein Binding

Yeung, C.Y.; Lee, F.T.; Wong, H.N 98

Intestinal Absorption of Macromolecules and Epithelial Cell Surface Glycosylation in Suck ling Rats Nursed on Mothers Fed Low-Protein Diet-I

Babbar, H.S.; Jaswal, V.M.S.; Gupta, R.; Mahmoud, A 104

Neonatal and Adult Patterns of Lectin Binding to Rat Small Intestinal Microvillus Mem branes

Stern, M.; Gellermann, B.; Schall, 1112

Erratum 120

Original Paper

Surfactant Replacement in Spontaneously Breathing Babies with Hyaline Membrane

Disease - A Pilot Study

Victorin, L.H.; Deverajan, L.V.; Curstedt, T.; Robertson, B 121

Effects of Maternal Hyperoxygenation on Atrioventricular Velocity Waveforms in Healthy and Growth-Retarded Fetuses

Rizzo, G.; Arduini, D.; Romanini, C; Mancuso, S 127

Renal Effects of Caffeine in Preterm Infants

Gillot, I.; Gouyon, J.B.; Guignard, J.P 133

Simultaneous Estimation of Neonatal Total Body Water by Antipyrine and H2180

Dilution

Brans, Y.W.; Kazzi, N.J.; Andrew, D.S.; Schwartz, C.A.; Carey, K.D 137

The Ability of Granulocytes to Generate Superoxide Anions and Hypochlorite during

Phagocytosis: Comparison of Neonatal Granulocytes with Adult Granulocytes

Nishida, A.; Kimura, H.; Sugioka, K.; Nakano, M 145

Regulation of Hepatocyte-Specific Gene Expression in Cultures of Human Embryonic

Hepatocytes

Roon, M.A. van; Zonneveld, D.; Boer, P.A.J. de; Moorman, A.F.M.; Charles, R.;

Lamers, W.H 152

An Explanation for Ketogenesis by the Intestine of the Suckling Rat: The Presence of an

Active Hydroxymethylglutaryl-Coenzyme A Pathway

Békési, A.; Williamson, D.H 160

Impaired Random Migration and Special Reactivity to Methylprednisolone in Young

Guinea Pig Macrophages

Prokic, L.M.; Vilic, I.M 166

Effects of the Antiglucocorticoid RU 486 on the Initiation of Ultrastructural Type-II Cell

Differentiation in Fetal Rat Lung

Guettari, N.; Dufour, M.-E.; Marin, L 173

Contents

$\mathrm{V}$

No. 4 Original Paper 
Cardiac and Respiratory Responses to Esophageal Dilatation during REM Sleep in Human Infants

Ramet, J.; Praud, J.-P.; d'Allest, A.-M.; Dehan, M.; Guilleminault, C; Gaultier, C. .181 Hypersomatotropism in the Dysmature Infant at Term and Preterm Birth de Zegher, F.; Kimpen, J.; Raus, J.; Vanderschueren-Lodeweyckx, M 188

Effect of Sympathetic Nervous System on Cerebral Blood Flow in the Newborn Piglet Monin, P.; Feillet, F.; Hascoet, J.-M.; Vert, P

Effect of Acetazolamide on Cerebral Blood Flow Velocity and C02 Elimination in Normotensive and Hypotensive Newborn Piglets

Thoresen, M.; Whitelaw, A 200

Regional Circulatory Responses to Hindlimb Work in Developing Swine

Buckley, N.M.; Frasier, I.D 208

Plasma Cortisol Distribution in the Pig from Birth to Six Weeks of Age

Kattesh, H.G.; Charles, S.F.; Baumbach, G.A.; Gillespie, B.E 220

Insulin Receptors in Developing Rat Liver. Receptor Autophosphorylation and Phosphor-

ylation of the Endogenous Substrate pp120/HA4 (ecto-ATPase) in Fetal and Neonatal

Liver

Margolis, R.N.; Tanner, K.; Seminara, D.; Taylor, S.I

Umbilical Cord Separation: Histological Findings and Perinatal Factors

Oudesluys-Murphy, A.M.; den Hollander, J.C.; Hop, W.C.J236

No. 5 Original Paper

Randomized Study of Vancomycin Pharyngeal Instillation as a Prophylaxis of Bronchopulmonary Infection in Intubated Neonates

Marchand, S.; Poisson, D.; Borderon, J.C.; Gold, F.; Chantepie, A.; Saliba, E.; Lau-

gier, J 241

Occurrence of Bifidobacterium in the Feces of Newborns Delivered by Cesarean Section

Bezirtzoglou, E.; Romond, C 247

Polymophonuclear Leucocyte and Natural Killer Cell Functions in Mature and Premature

Newborns

Rabatic, S.; Benic, L.; Mazuran, R.; Dekaris, D

Impaired Interferon-Alpha Enhancement of Neonatal Monocyte Phagocytosis

El-Mohandes, A.E.; Brudno, D.S.; Ahronovich, M.D 260

N-Terminal Propeptide of Type-Ill ProcoUagen Concentrations in the Cord Blood: An

Index of Newborn Maturity

Yunoki, H.; Yagi, H.; Nagashima, K.; Noji, T.; Miyake, H.; Kuroume, T 264

Prostacyclin-Like Activity in Umbilical Arteries Is Dose-Dependently Reduced by Maternal

Smoking and Related to Nicotine Levels

Ahlsten, G; Ewald, U.; Tuvemo, T 271

Development of Bile Secretory Function in the Neonatal Guinea Pig

Tuchweber, B.; Ducruet, N.; Perea, A.; Yousef, I.M.; Weber, A.M 279

Nuclear 3,5,3'-Triiodothyronine Receptors in Skeletal Muscle of Normal and Small-for-

Gestational Age Newborn Piglets

Dauncey, M.J.; Geers, R 291

Respiratory Response to Adenosine in Newborn Lambs Is Modified by Hypoxemia and by Heat Stress

Norsted, T.; Jonzon, A.; Sedin, G 296 


\section{Contents}

No. 6 Original Paper

Glutathione Peroxidase and Selenium Levels in the Preterm Infant

Tubman, T.R.J.; Halliday, H.L.; McMaster, D 305

Key Enzymes of Purine Degradation and Reutilization in Human Fetal Liver and Brain

Vettenranta, K.; Raivio, K.0 311

Effect of Maternal Vitamin-A Administration on Fetal Lung Vitamin-A Stores in the Perinatal

Rat

Shenai, J.P.; Chytil, F 318

$\alpha$-Fetoprotein in Congenital Hypothyroidism

Mengreli, C; Sarafidou, E.; Petmezaki, S.; Pantelakis, S 326

Intestinal Permeability to Intact Lactose in Newborns and Adults

Bezerra, J.A.; Thompson, S.H.; Morse, M.; Koldovský, O.; Udall, J.N., Jr 334

Levels of Insulin-Like Growth Factor I in Full-and Preterm Human Milk in Comparison to

Levels in Cow's Milk and in Milk Formulas

Nagashima, K.; Itoh, K.; Kuroume, T343

The Uptake of Amino Acids and Oxygen across the Rabbit Uterus in Normal and Postterm Pregnancies

Li, H.-Q.; Gilbert, M.; Teng, C; Jones, R.O.; Murray, R.D.; Battaglia, F.C 347

Author Index 355

Subject Index 357

Suppl. 1 'Metabolic Problems of the Newborn'

Proceedings of the I Vth International Symposium on Neuronatology: An Update Venice, March 29-31, 1990 